Chirurgia (2020) 115: 690-694

No. 5, September - October

Copyright@ Celsius

http://dx.doi.org/10.21614/chirurgia.115.5.690

\title{
Successful Treatment of Major Abdominal Trauma in a 9-year-old Male due to Bomb Explosion
}

\author{
Ahmet Atıcı ${ }^{1 *}$, Mustafa Özkan², Mehmet Emin Çelikkaya ${ }^{1}$, Bülent Akçora ${ }^{1}$ \\ ${ }^{1}$ Department of Pediatric Surgery, Mustafa Kemal University, School of Medicine, Hatay, Turkey \\ 2Department of Plastic Surgery, Mustafa Kemal University, School of Medicine, Hatay, Turkey
}

*Corresponding author:

Ahmet AtıcI, MD

Mustafa Kemal University

School of Medicine

Department of Pediatric Surgery

31124, Antakya, Hatay, Turkey

E-mail: ahmetatici06@gmail.com ahmetim1501@hotmail.com

\section{Rezumat}

Tratamentul cu succes al traumei abdominale majore la un pacient de 9 ani cauzat de explozia unei bombei

Prezentul raport de caz descrie un pacient pediatric care a suferit şi a supraviețuit unui traumatism abdominal major datorat unei explozii în aer liber în timpul războiului civil sirian. Un pacient de 9 ani, de sex masculin, a fost adus la secția de urgență pediatrică a spitalului nostru după explozia unei bombe care a avut loc cu 8 ore înainte de prezentare. Pacientul avea un defect cutanat asemănător unui lambou care se extindea de sub ombilic la femurul drept. Defectul a avut încorporate multiple pietre, plastic şi fragmente de sol de dimensiuni diferite. S-a efectuat deshidratarea peretelui abdominal anterior, urmată de laparotomie exploratorie. Au fost rezecate mai multe perforații ale intestinului subțire şi $\mathrm{s}^{-a}$ efectuat anastomoză. Inchiderea asistată sub vid (VAC) a fost aplicată pe zona mare a plăgii. Pansamentul VAC a fost schimbat la fiecare 3 zile. Țesutul de granulație s-a dezvoltat post-operator după 26 de zile şi defectul a fost reparat folosind grefe de piele recoltate de la piciorul stâng al pacientului. Pacientul a fost considerat complet recuperat şi a fost externat la 34 de zile după operație. Cazul prezentat arată că, în ciuda gravității leziunilor abdominale majore ale pacientului, debridarea rapidă a plăgilor, laparotomia exploratorie, terapia VAC şi o abordare multidisciplinară sunt cruciale în prevenirea decesului şi realizarea unei recuperări complete.

Cuvinte cheie: traume abdominale, explozii cu bombe, copii 


\section{Abstract}

The present case report describes a pediatric patient that sustained and survived major abdominal trauma due to an open-air explosion during the Syrian civil war. A 9-year-old male patient was brought to our hospital's paediatric emergency department after a bomb explosion that occurred 8 hours prior to presentation. The patient had a severe flap-like skin defect that extended from the below the umbilicus to the right femur. The defect was embedded with multiple stones, plastic, and soil fragments of varying size. Debridement of the anterior abdominal wall was performed, followed by exploratory laparotomy. Multiple sites of perforation of the small bowel were resected, and anastomosis was performed. Vacuum-assisted closure (VAC) was applied to the large wound area. The VAC dressing was changed every 3 days. Granulation tissue developed post-operatively after 26 days and the defect was repaired using skin grafts harvested from the patient's left leg. The patient was considered fully recovered and was discharged 34 days post-surgery. The presented case shows that despite the severity of the patient's major abdominal injuries, rapid wound debridement, exploratory laparotomy, VAC therapy and a multidisciplinary approach are crucial in preventing death and achieving a full recovery.

Key words: Abdominal trauma, bomb explosions, children

\section{Introduction}

As modern warfare and terrorism often occur in areas populated by civilians, the number of children injured as a consequence is increasing (1). Due to their developmental characteristics, children are more severely affected by explosion injuries than adults (2). When the human body is exposed to a bomb explosion, the energy released by the explosion is transferred to human tissues, resulting in mortal injuries, especially in children (3). Abdominal trauma in children is common and frequently occurs due to falling from a height, falling from a bicycle, and traffic accidents, whereas major abdominal trauma due to bomb explosions is very rare, but often fatal (1). The present case report describes a pediatric patient that sustained and survived major abdominal trauma due to an open-air explosion during the Syrian civil war.

\section{Case Report}

A 9-year-old male presented to our hospital's pediatric emergency department after sustaining injuries from a bomb explosion that occurred 8 hours prior to presentation. Physical examination showed that the patient's general condition was poor, $\mathrm{SaO} 2$ was $92 \%$, body temperature was $38.2^{\circ} \mathrm{C}$, pulse rate was $102 \mathrm{bpm}$, respiratory rate was 38 breaths per minute, and blood pressure was $110 / 60 \mathrm{~mm} / \mathrm{Hg}$. Blood count and biochemistry findings were normal, except for a low hemoglobin level $(8.7 \mathrm{~g} / \mathrm{dl})$.

The patient had a severe flap-like skin defect that extended from the abdomen (below the umbilicus) to the right femur, which was considered an avulsion injury. The patient's skin and subcutaneous adipose tissue were absent throughout this region. The fascia was intact, except for a $3 \times 5-\mathrm{mm}$ area in the left lower quadrant that was thought to be a foreign body entrance hole. The left external oblique and bilateral rectus abdominis muscles were intact. The inferior part of the right external oblique muscle and superior part of the right gluteus medius muscle were irregularly fragmented, and both had tissue loss (Fig. 1). The defect was embedded with multiple stones, plastic, and soil fragments of varying size (Fig. 1). An 
abdominal CT scan showed free air within the abdominal cavity and a metal foreign body measuring approximately $4 \mathrm{~cm}$. Paediatric Trauma Score was used to assess the case and the paediatric trauma score was 8 . The patient immediately underwent emergency surgery performed by a pediatric surgeon and plastic surgeon. Within $30 \mathrm{~min}^{-}$ utes of presenting to the emergency room, the patient was administered $0.9 \%$ sodium chloride (20 mL kg-1 of body weight). During surgery, the patient was administered erythrocyte suspension $(10 \mathrm{~mL} \mathrm{~kg}-1$ of body weight). Debridement of the anterior abdominal wall was performed, followed by exploratory laparotomy. Intraoperative findings included a metal foreign body, which was removed from the abdominal cavity. Multiple sites of perforation along two segments (approximately $5 \mathrm{~cm}$ long) of the small bowel were resected, and anastomosis was performed manually. Intraoperative peritoneal lavage was performed with saline solution. Vacuum-assisted closure (VAC) was applied to the large wound area, and then the patient was transferred to the intensive care unit. Postsurgery, the patient was administered $0.9 \%$ sodium chloride as maintenance fluid therapy (70 mL h-1). Intravenous ceftriaxone and metronidazole were administered for ten days postoperatively. The VAC dressing was

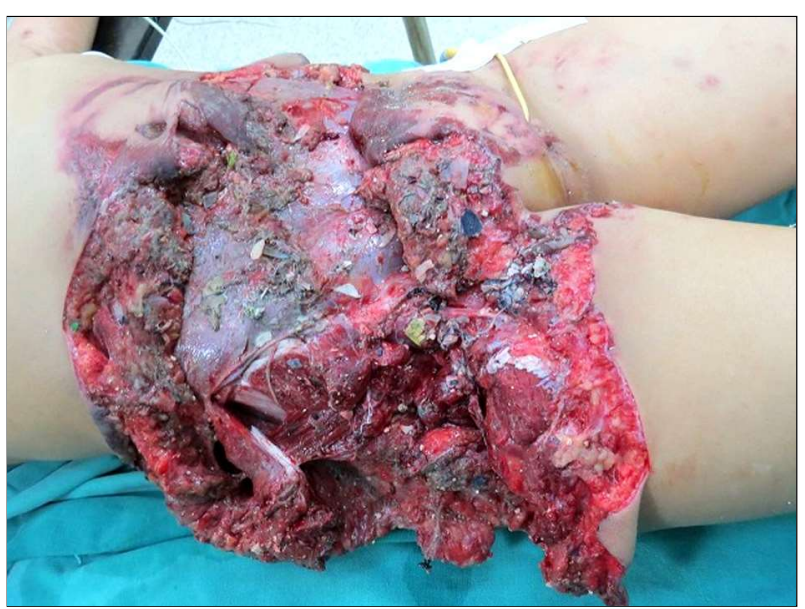

Figure 1. Severe flap-like skin defect extending from the abdomen below the umbilicus to the right femur changed every 3 days. Oral food intake was resumed on the $4^{\text {th }}$ day postsurgery. Granulation tissue developed post-operatively on day 26 (Fig. $2 \mathrm{~A}$ ). and the defect was repaired using skin grafts harvested from the patient's left leg. The patient was considered fully recovered and was discharged 34 days post-surgery (Fig. 2 B,C). The patient's parents provided written informed consent for publication of their son's case.

\section{Discussion}

Bomb explosion victims sustain direct or indirect complex injuries due to the explosion's shock wave immediately following the explosion or sometime afterwards $(3,4)$. A temporary hyper-pressure phase of the shock wave occurs after the explosion, and its speed quickly decreases with distance (3). There is a positive correlation between the level of energy from an explosion transferred to the human body and the magnitude of injury it causes (3). There is also an inverse correlation between the distance from an explosion and the severity of explosion-associated injury (3). Explosions can cause injuries to multiple organs and systems, including the vasculature, visceral and solid organs, and extremities. In general, there are three types of explosion-related injuries:

1. Primary explosion injuries occur due to the direct interaction between the human body and the shockwave hyper-pressure phase. Most physio-pathological effects on the body are caused by the results of the extreme differences in pressure occurring on the body's surfaces. Primary explosion injury is most commonly observed in gas-containing organs, such as the middle ear, lungs, and intestines.

2. Perforating injuries are caused by foreign bodies radiating out from the bomb and/or from the environment that enter a victim's body.

3. Burn injuries, irradiation injuries, and smoke inhalation and suffocation can also occur due to bomb explosions (3-5).

The presented patient had all three types 


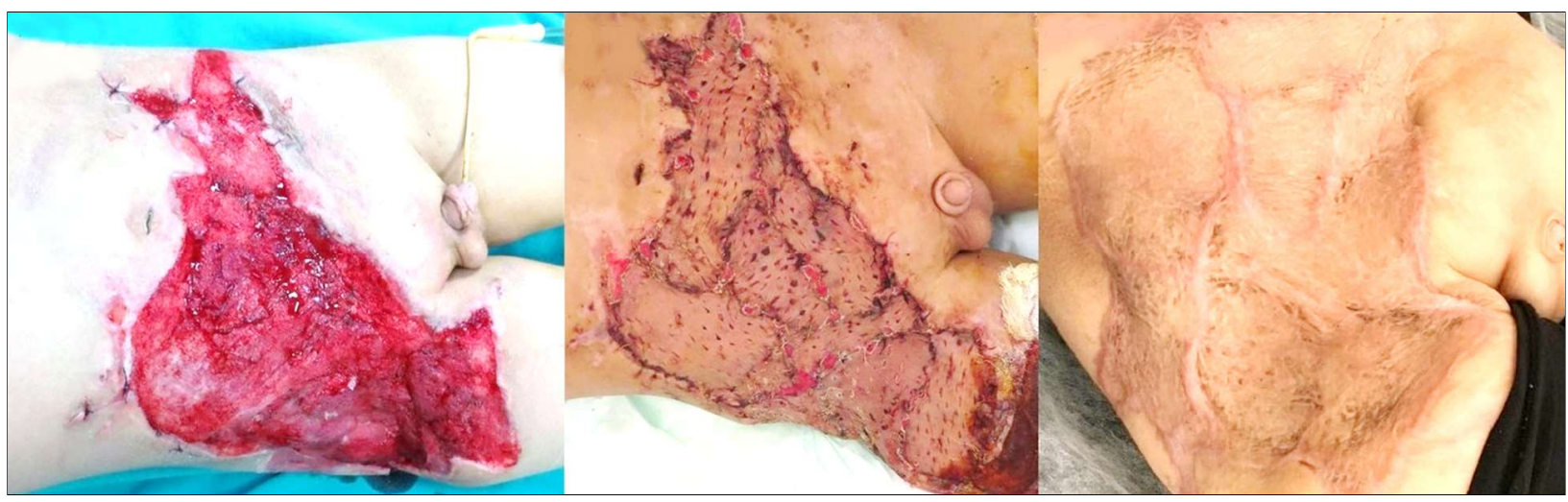

Figure 2. (A) Granulation tissue developed. (B) The defect was repaired with skin grafts harvested from the leg.

(C) Postoperative 2nd month

of explosion injuries (Fig. 1). The presence of stones, soil, and plastic in the patient's body suggests that he was knocked down by the explosion's shock wave. The foreign body removed from the patient was considered to have entered his body due to the force of the explosion and caused the observed intestinal perforation.

According to the literature, explosions most commonly cause soft tissue, head, and orthopaedic injuries (5). In contrast, the presented patient had severe soft tissue injuries and responded remarkably well to VAC therapy. The most commonly injured intra-abdominal organ is the small intestine, followed by the colon and liver (6). The small intestine and colon, which are hollow organs, are the most common abdominal regions affected by haemorrhage and perforation (5). Moreover, due to subsequent tension, ischemia, weakening of the intestinal wall, and acute or late perforation can be observed in the intestines for several days (5). According to the literature, primary repair is preferred over colostomy/ileostomy in 66\%$100 \%$ of gunshot injuries involving the abdominal cavity (7). In the presented case, resection and anastomosis of two intestinal segments were performed rather than ileostomy because only 8 hours had elapsed since the injury was sustained, and the duration of contamination was minimal. The patient did not develop any anastomotic complications post surgery. Timely treatment of severe injuries is known to positively affect survival, (5) which is further illustrated in the case of the presented patient, who survived a severe abdominal injury due to a bomb explosion (treatment began within 8 hours of sustaining the explosion-related injuries).

\section{Conclusion}

Treatment of patients with major abdominal injuries due to bomb explosions is challenging and requires a prolonged treatment period. Patients should be monitored by a multidisciplinary team under intensive care unit conditions. The presented case shows that despite the severity of the patient's major abdominal injuries, rapid wound debridement, exploratory laparotomy, VAC therapy and a multidisciplinary approach are crucial in preventing death and achieving a full recovery.

\section{Conflict of Interest}

The authors declare no conflicts of interests.

\section{References}

1. Aylwin CJ, König TC, Brennan NW, Shirley PJ, Davies G, Walsh MS, et al. Reduction in critical mortality in urban mass casualty incidents: analysis of triage, surge, and resource use after the London bombings on July 7, 2005. Lancet. 2006;368(9554): 2219-25. 
2. Parikh K, Silver A, Patel SJ, Igbal SF, Goyal M. Pediatric FirearmRelated Injuries in the United States. Hosp Pediatr. 2017;7(6): 303-312.

3. Prat NJ, Daban JL, Voiglio EJ, Rongieras F. Wound ballistics and blast injuries. J Visc Surg. 2017;154 Suppl 1:S9-S12.

4. Champion HR, Holcomb JB, Young LA. Injuries from explosions: physics, biophysics, pathology, and required research focus. J Trauma. 2009;66(5):1468-77; discussion 1477.

5. Wightman JM, Gladish SL. Explosions and blast injuries. Ann
Emerg Med. 2001;37(6):664-78.

6. Iflazoglu N, Ureyen 0, Oner OZ, Tusat M, Akcal MA. Complications and risk factors for mortality in penetrating abdominal firearm injuries: analysis of 120 cases. Int J Clin Exp Med. 2015;8(4):615462. eCollection 2015.

7. Velmahos GC, Souter I, Degiannis E, Hatzitheophilou C. Primary repair for colonic gunshot wounds. Aust N Z J Surg. 1996; 66(6):344-7. 